\title{
6. Organization advantage: Experience of telework in India
}

\section{Ernesto Noronha and Premilla D'Cruz}

\section{EXECUTIVE SUMMARY}

Early work on teleworking in India focused on its feasibility in terms of the availability of telecommunications infrastructure. Power failures and fluctuations meant that installation of generators was required to ensure a steady flow of electricity and connectivity. Furthermore, it was necessary to ensure that computers and telephone connections were affordable for teleworking to succeed (Aundhkar et al. 2000; Irani et al. 2000). Since then broadband penetration has increased many times over, with mobile phone connections becoming common, which increases the feasibility of implementing a telework programme. More recently, the Digital India programme launched by the Government of India (GOI) to provide high-speed Internet connectivity across the length and breadth of the country (GOI 2015) should provide a boost to telework.

Since the literature on telework in India is limited, we undertook a fresh survey of 1047 employees working across several business sectors from around the country. Of those working as teleworkers, the largest share came from information technology and information technology enabled services (IT/ITES) (12 per cent), followed by hospitality (11 per cent), telecommunications ( 9 per cent), manufacturing ( 8 per cent) and financial services ( 7 per cent). This means that in comparison to earlier studies which found teleworking to be restricted to IT, finance and media, our study finds that it has spread to other sectors as well.

Another interesting finding is that it is often argued that teleworking is most suitable for women, particularly in the Indian context. Women find it difficult to pursue their careers, especially when their children are young. Those who do so have to manage many demands of family life plus the stress of their careers, which is often detrimental to their health. Telework is seen as a way out of the situation, which allows them to be connected to their careers from their homes and also organize their time better 
(Aundhkar et al. 2000; Gothoskar, 2000; Irani et al. 2000). Thus, telework in India is assumed to be a gendered phenomenon. However, when disaggregating for gender our findings show that more women worked from the office ( 82 per cent) than teleworked (19 per cent), which was similar for men. Thus, contrary to the existing belief, women do not always prefer to telework, while men could also be interested in teleworking. This may also be related to the policy of organizations that do not distinguish between men and women when deciding who teleworks; the definition of telework, which means any place away from the office rather than solely home-based work; and the nature of the workplace, which in the case of men means third spaces. Nonetheless, it is significant to note that, in general, women also prefer working in the office.

Across the entire sample, most of the respondents worked in jobs which had regular timings ( 98.5 per cent). Eighty-four per cent of all those working from the office worked for nine hours or less. This dropped to 81 per cent for those teleworking. However, those working beyond 6.00 p.m. from the office were 54 per cent, while the proportion was higher (66 per cent) for those teleworking. A further disaggregation of teleworkers reveals that this figure was 75 per cent for those working from a combination of spaces - that is, the office and any place other than the office. This means that, although those working from the office also worked long hours, the numbers increased for those working from places besides the office. While 84 per cent of those working in the office stated that they did not receive overtime payments for work beyond nine hours, this was 89 per cent in the case of teleworkers. This means that payment of overtime rates ceased to exist in general, but those working from the office still stood a chance of getting payments - a chance which was almost non-existent for those working from beyond the office.

Although it was obvious that those working from other places would take breaks, as that defined the flexibility that telework offered, we found that even those working in the office ( 45 per cent) took more than the stipulated breaks, often resulting in stretched hours of work. This may partially account for them working more than nine hours, beyond $6.00 \mathrm{pm}$ or on weekends, reflecting the Indian work ethic (see D'Cruz and Noronha 2012). A substantial number of teleworking employees (51 per cent) reported that they worked all the time.

With regard to getting time off to take care of personal matters, teleworking employees seemed divided, with 50 per cent stating that they quite often or mostly got time off, while the other half stated that this was possible only occasionally, never or rarely. Therefore, most of those teleworking maintained strict working hours (53 per cent) and separate work spaces to enable them to work effectively. With regard to the former, 
it called for being self-accountable, self-motivated, self-governed and self-managed, with a high sense of moral and professional integrity (Rajan 2000), giving the impression of a more empowering work relationship (Gothoskar 2000).

Despite this, managers called teleworkers frequently to check on them and pressurize them to come to the office more regularly (Raghuram 2014). Not surprisingly, a substantial number (46 per cent) stated that they were on work-related calls quite often or most of the time with 27 per cent being on calls occasionally. This mindset probably gets reflected in organizational polices that require teleworkers to be available at any hour, log on for a given number of hours, complete a given amount of work every day, contact the office at given intervals (Rajan 2000) and have regular email communications, which are followed up by weekly meetings (Aundhkar et al. 2000). Moreover, normative control is also invoked to ensure the creation and maintenance of a strong organizational culture that increases employees' commitment to organizational values and their identification with the organization (Noronha and D'Cruz 2008b). Regarding careers, the response is mixed, with some arguing that teleworking did not hamper career prospects, while others argued that out of sight was out of mind and also that the productivity of teleworkers declines over a period of time (Chowdary and Jayakumar 2009).

Another issue pertains to infrastructure. Teleworkers were expected to install an inverter in their houses to manage power failures and utilize their own equipment, although software and a fixed amount of telephone costs are paid by the organization (Noronha and D'Cruz 2008b). In our sample, to enable employees to work from home, employers mainly provided laptops (58 per cent) and desktop computers (31 per cent). The other types of devices provided were telephones, that is, land lines, mobile phones and smartphones. It seems that employers benefited from teleworking. About 80 per cent of the respondents resoundingly agreed that employers gained from teleworking in terms of productivity and efficiency, while 76 per cent stated that employers gained from better quality work. The other parameters on which more than half of the respondents agreed or strongly agreed are cost savings (53.4 per cent), flexibility (58.3 per cent), customer satisfaction (60.8 per cent) and virtual teamwork (53.9 per cent). Despite these benefits accruing to employers, teleworking cannot be a universal policy covering all jobs and industries. In those jobs and industries that require the physical presence of employees or where issues related to privacy, control and data security are critical, teleworking cannot be introduced (Chowdary and Jayakumar 2009; Mitter 2000; Rajan, 2000). Further, in order to ensure that teleworking works well, organizations should have a good management by objectives programme, 
which ensures that deliverables are achieved and goals are met (Chowdary and Jayakumar 2009). Moreover, organizations have allowed only those who had worked as full-time office employees and had achieved a certain level of proficiency in their jobs to opt for telework (Noronha and D'Cruz 2008b). Finally, although the decision to telework was motivated primarily by domestic or family concerns, teleworking was construed as an opportunity to continue in the realm of paid employment while simultaneously fulfilling home-related responsibilities (Noronha and D'Cruz 2008b). However, the perception is that teleworking is not recommended as a substitute for childcare, and some organizations even specify that the location of the teleworking should be free of distractions for a major part of the day.

\section{INTRODUCTION}

Telecommuting as a formal practice has its origins in the USA (Raghuram 2014; see also the Introduction in this volume) and is often used interchangeably with the term teleworking (Mitter 2000). In India, the concept of telework is more commonly understood in the context of internationally outsourced work in software services or remote data processing (Mitter 2000), which Mitter and Sen (2000) define as teletrade. While some argue that telework as a concept and as a practice is still in the process of evolving in India (Chowdary and Jayakumar 2009; Gothoskar 2000) and is not as yet as widespread (Mitter 2000), Lila and Anjaneyulu (2013) assert that all modes of telework, such as working from home, mobile teleworking, teleconferencing, offshore teleworking, self-employed teleworking and teleworking centres (on a minuscule level), exist in India. Nonetheless, offshore outsourcing in the service industry seemed to provide the immediate inducement for teleworking in India (Aundhkar et al. 2000), since Indian employees had to work at atypical hours to cater to clients in different time zones, thereby relieving them of the need to be present in office at these unusual times (Raghuram 2014).

\section{TELEWORKING IN INDIA - PAST RESEARCH}

Given this development, it was quite natural for employees from the IT/ ITES sector to be more likely to be able to telework than those from other sectors, which required physical presence and interactions with their colleagues and the public (Lila and Anjaneyulu 2013). However, although the IT/ITES industry took the lead in facilitating telework, the finance 
and media sectors were not far behind (Aundhkar et al. 2000; Gothoskar 2000). In the finance sector, the emphasis was not so much on connecting distant employees to the core office, but rather on tele-networking (Mitter 2000). Nonetheless, where required, field-based employees reported their activities to personnel in the branch office, who then fed the information into the computer or the service centre (Aundhkar et al. 2000), while media employees and freelancers frequently used cybercafés, telecentres, tele-cottages or computer centres to submit news reports and to coordinate television programmes (Mitter 2000). Accordingly, the employees most susceptible to telework were journalists, researchers, accountants, publishers, software developers and back-office personnel. Over the years, others type of activities, such as data conversion, data processing, medical transcription, content development, deposition summaries, insuranceclaim processing, marketing, communications, customer support service, sales transactions banking, secretarial work and geographical information systems, were also seen as being compatible with teleworking (Gothoskar 2000; Irani et al. 2000).

Several benefits have been highlighted for adopting teleworking in countries such as India. These benefits include the ability of teleworkers to work more hours than their office-bound colleagues by saving time on commuting and long lunch breaks (Chowdary and Jayakumar 2009; Noronha and D'Cruz 2008b). Further, according to employers, teleworking allows more flexibility, makes it easier to meet deadlines and cuts down production time (Aundhkar et al. 2000) by using employees effectively, profitably and reducing costs (Irani et al. 2000; Mitter 2000; Rajan 2000). From the employees' perspective, teleworking improves their quality of life by facilitating work-life balance, especially for women with small children and disabled employees who would normally have to give up their careers (Aundhkar et al. 2000; Lila and Anjaneyulu 2013; Rajan 2000). In addition to teleworking offering employees the opportunity to combine family with career (Mitter 2000; Noronha and D'Cruz 2008b), it also helps them economically and provides them, especially women, with a sense of purpose (Noronha and D'Cruz 2008a).

Teleworking is seen as a way out of the situation for women because it allows them to be connected to their careers and to organize their time better (Aundhkar et al. 2000; Gothoskar 2000; Irani et al. 2000). Yet it is difficult to ensure that women can progress to higher value-added jobs. However, women do not always prefer to be home-based workers, and this is true not only of young middle-class women, but also of mothers with young children who often express their need to go out to work in order to avoid loneliness and alienation (Mitter 2000). Thus, women's approach to telework is more complex than that of men. The social pressures of having 
to balance the demands of family and career force them to telework, which in the process may potentially also change their employment status from that of full-time employee to freelance consultant (if the company for whom they work does not permit their employees to telework), while simultaneously excluding them from organizational benefits and privileges (Mitter 2000).

However, there is a resistance to the externalization of work from the office, both from employers and from employees. From the employers' perspective, teleworking is still viewed with circumspection, as it erodes the advantages of face-to-face interaction which are presumed to generate competence and company loyalty, impacting on the quality of services and delivery time. It also makes the task of evaluating employees' performance more difficult within the prevalent management traditions, which still place importance on personal interaction, direct supervision and strict monitoring. Managers are concerned about the inefficiencies arising out of the lack of supervision and personal contact, and as well as maintaining the confidentiality of sensitive information (Irani et al. 2000; Mitter 2000). These apprehensions could be reasons why the tasks performed by Indian teleworkers are often less complex and need comparatively little monitoring (Mitter 2000). However, some predict that telework is likely to expand to cover highly skilled jobs, as well as jobs with no prospect of career progression in the future (Gothoskar 2000).

Employees felt that teleworking is good for the company, but bad for the individual in the long run, as it could lead to isolation and alienation (Aundhkar et al. 2000). From the employees' point of view, the notion of working from home is not without worries (Mitter 2000). In general, teleworkers were likely to feel more insecure, lose their bargaining power, be deprived of workplace culture, camaraderie and security, be more susceptible to non-payment by clients or employers, be more likely to lack a labour organization to deal with issues of pay, health and safety, have less access to training, advancement and benefits, and feel increased stress on the job; in particular, women were likely to face the reinforcement of their roles in the home, denial of legitimate access to public and social spaces, and reinforcement of women's basic vulnerability as women and as workers (Gothoskar 2000). While work constituted a critical component of the identity of female teleworkers, they continued to view their domestic roles, and especially their maternal role, as central, and they constructed telework as a flexible strategy providing an opportunity to combine this role with paid work. Thus, engagement with telework often operated to confirm women's traditional gender identity, perpetuating the gendered division of domestic responsibilities and gendered ideologies within the household. Yet, being able to manage so many activities was not easy, given 
the organization's expectations regarding the quality and quantity of work. Being able to cope was contingent on their specific family situation, the availability and nature of support, and their structuring and/or extending the workday. Teleworking, while providing a solution to a set of dilemmas, presents challenges of its own (Noronha and D'Cruz 2008b).

\section{METHODOLOGY}

According to the guidelines provided by the International Labour Organization (ILO), information for this study was to be obtained from surveys, datasets, studies, articles and other sources of information already available in the country; no new data collection was required. Available information - both quantitative and qualitative - was to be compiled using a standard expert questionnaire developed by Eurofound and the ILO. In the first stage of the study, all the required information in the standard questionnaire was to be completed, and the second stage involved preparing a report that synthesized information for possible publication. Telework was defined as using ICTs, such as smartphones, tablets, laptops or desktop computers, for work away from the employer's premises. However, since there is little or no information relating to teleworking in India (Jones 2005) and the data required for the study could not be accessed from the existing literature, the researchers decided to undertake a fresh survey. Using a database from a recruiting firm, emails were sent out to more than 25000 people. In addition, emails were also sent out to employees who we had contacted earlier for our various studies on the IT/ITES sector. Nonetheless, our final sample was 1047, after dropping about 50 participants whose data was not complete or who were not working currently in India (but were looking for the jobs in India). This was a 4 per cent response rate with a tilt towards the IT sector. The results of about 1047 respondents were analysed for this report; these include both those who telework (19.5 per cent) and those who do not telework ( 80.5 per cent). For the purpose of this analysis, the teleworkers were categorized into those working only from home, those working any other place besides the home, and those working from a combination of places. The survey was conducted by research staff telephonically at a time that was convenient for the respondents, after the participants had agreed to participate and sent back their telephone numbers. Efforts were also made to check the authenticity of the data collected by randomly telephoning participants who took part in the survey.

Since the purpose was to get adequate representation of teleworkers across economic sectors, there was no particular effort made to achieve a regional representation. Nevertheless the sample seemed to be spread 
out quite evenly, with 33 per cent of the respondents coming from West India (which includes Mumbai, Pune and Ahmedabad), 28 per cent from North India (mainly Delhi and the National Capital Region), 25 per cent from South India (mainly Chennai, Bangalore and Hyderabad), and the rest from East and Central India (mainly Kolkata). Nonetheless, some effort was made to get an even industrial representation by sending out emails to equal numbers of participants from all the sectors; however, this was largely unsuccessful, as we did not get equal numbers of return responses. Regarding industry, although theoretically we wanted an equal representation from each industry, it was not possible and was dependent on those who agreed to take the survey. Although there was no deliberate attempt to bias the sample towards the IT/ITES sector, our research in the field for several years and their adeptness with technology tilted the sample towards this sector. However, studies researching teleworking in India have long focused on this sector, as there was an assumption that this sector would be most susceptible to technology. For instance Mitter (2000) states that her sample was deliberately biased towards big establishments, and towards emerging sectors, such as software, that are likely to adopt teleworking. Later, Noronha and D'Cruz (2008a, 2008b) focused their study on medical transcriptionists who we have included in the IT/ITES sector. More recently Lila and Anjaneyulu (2013), in addition to focusing on areas of finance, sales, human resources and marketing, also considered the job profiles of those working in the IT/ITES sector. Finally, the basis of Raghuram's (2014) work is the experience of teleworking in the IT sector, whose characteristics support the use of teleworking programmes. Thus, the bias towards the IT/ITES sector is not by design, but has been accidently relevant. However, what may be relevant to IT could also be applicable to other organizations, such as consulting, as they confront similar problems and benefits (Raghuram 2014). The other sectors also often explored are media and finance (Mitter 2000). Our survey once again reveals that the sample was primarily tilted towards IT/ITES (12 per cent) and hospitality (11 per cent), followed by telecommunications ( 9 per cent), manufacturing ( 8 per cent) and financial services ( 7 per cent).

Simultaneously, all the existing studies on teleworking in the Indian context were reviewed and all newspaper articles scanned for information. Since the survey did not pick up information on the organizational polices, as most teleworking was an informal arrangement between supervisors and employees, organizations who had formal policies were contacted and their human resource (HR) managers interviewed. Finally, five case studies of organizations were constructed, representing IT, finance, manufacturing, publishing and consulting sectors, in order to understand their organizational practices. 


\section{INCIDENCE OF TELEWORK}

Of those interviewed 80.5 per cent worked from the office and only 19.5 per cent teleworked. Of those teleworking, employees using a combination of different spaces were the highest, at 65.7 per cent; 27.5 per cent worked from a place other than home or the office; and just 6.9 worked only from home (Table 6.1).

The sample consisted of 79 per cent males and 21 per cent females. The low representation of women in the sample could be related to India's rate of female participation in the labour force being the lowest among the BRIC (Brazil, Russia, India and China) countries (Lila and Anjaneyulu 2013). When disaggregating for gender we find that more women worked from the office ( 82 per cent) than teleworked (19 per cent), while the males working from the office were 80 per cent, with male teleworkers being 20 per cent (Table 6.2). Thus, contrary to belief, women do not always prefer to telework and males could also be interested in teleworking. This may be related to the policy of some organizations, which does not distinguish between men and women when deciding who teleworks; the definition of telework, which means any place other than the office rather than only home-based work; and the nature of the workplace, which for men means

\section{Table 6.1 Place of teleworking}

\begin{tabular}{lcc}
\hline Place of work & Frequency & Percentage \\
\hline Only home & 14 & 6.9 \\
Any place other than home or office & 56 & 27.5 \\
Combination of spaces - office and home & 134 & 65.7 \\
$\quad$ and any place other than home/office & & 100.0 \\
Total & 204 & \\
\hline
\end{tabular}

Table 6.2 Place of work by gender

\begin{tabular}{llcc}
\hline \multirow{2}{*}{ Gender } & \multicolumn{2}{c}{ Where do you work from } & \multirow{2}{*}{ Total } \\
\cline { 2 - 3 } & \multicolumn{2}{c}{ Office } & Telework \\
\hline Male & 667 & 164 & 831 \\
& $(80.3 \%)$ & $(19.7 \%)$ & $(100.0 \%)$ \\
Female & 176 & 40 & 216 \\
& $(81.5 \%)$ & $(18.5 \%)$ & $(100.0 \%)$ \\
Total & 843 & 204 & 1047 \\
& $(100.0 \%)$ & $(100.0 \%)$ & $(100.0 \%)$ \\
\hline
\end{tabular}


Table 6.3 Gender and teleworking (percentage)

\begin{tabular}{lccccc}
\hline Gender & Never & $\begin{array}{c}\text { Not on a } \\
\text { daily basis }\end{array}$ & $\begin{array}{c}\text { Once every } \\
\text { day }\end{array}$ & $\begin{array}{c}\text { Several times } \\
\text { a day }\end{array}$ & Always \\
\hline Male & 76.3 & 0.2 & 1.2 & 14.6 & 7.8 \\
Female & 78.7 & 0.0 & 0.0 & 10.1 & 11.2 \\
\hline
\end{tabular}

third spaces. Nonetheless, it is significant to note that even women typically prefer coming to the office.

Similarly, there was no major difference in the way men and women experienced teleworking. Seventy-six per cent of the men never worked from home, while this was 79 per cent for women (Table 6.3). Similarly, 11 per cent of the women always teleworked, and this was about 8 per cent for men. Thus, although there were more women working from the office, this tendency did not get reversed for those who were teleworking.

Given that Lila and Anjaneyulu (2013) argue that the responsibility towards the family, including the setting up of a house, providing education to children and doing other household tasks peaks at 30-40 years, it is not surprising that this was the preferred age group for telework. The average age of those teleworking in our sample was 31 years, with those in the teleworking group not only being between 30 and 40 years (38 per cent), but also a substantial number in the 20-30 years bracket (49 per cent); see Table 6.4.

Thus, there were those who were less than 30 years old who also teleworked, and it was not only those who were unmarried and had no household responsibilities who teleworked. Further, with most married persons in India falling in the age category of 30-40 years, Lila and Anjaneyulu (2013) argue that the marital status of employees influenced the choice of telework, with married people teleworking more frequently compared with unmarried people. Accordingly, those who teleworked and were married were the largest group (53 per cent of respondents), but there was also a substantial number (43 per cent) who were not married and still teleworked - breaking the myth that it was mostly those who were married who took to telework (Table 6.5).

Those who teleworked were better educated. Just over 50 per cent of those teleworking were postgraduates, while almost 36 per cent of teleworkers were graduates (Table 6.6). Thus, it was clear that the education level of teleworkers was high, and a larger portion of the sample would have used technology in their everyday life.

Eighty-eight per cent of teleworkers worked for private organizations, while only 8 per cent worked for public sector organizations. There were 
Table 6.4 Age and place of work

\begin{tabular}{lccc}
\hline \multirow{2}{*}{ Age } & \multicolumn{2}{c}{ Place of work } & \multirow{2}{*}{ Total } \\
\cline { 2 - 3 } & Office & Telework & \\
\hline Less than 20 & 1 & 0 & 1 \\
& $(0.1 \%)$ & $(0 \%)$ & $(0.1 \%)$ \\
$20-30$ & 486 & 98 & 584 \\
& $(58.1 \%)$ & $(48.5 \%)$ & $(56.2 \%)$ \\
$30-40$ & 281 & 76 & 357 \\
& $(33.6 \%)$ & $(37.6 \%)$ & $(34.4 \%)$ \\
$40-50$ & 55 & 19 & 74 \\
& $(6.6 \%)$ & $(9.4 \%)$ & $(7.1 \%)$ \\
50 and over & 14 & 9 & 23 \\
& $(1.7 \%)$ & $(4.5 \%)$ & $(2.2 \%)$ \\
Total & 837 & 202 & 1039 \\
& $(100 \%)$ & $(100 \%)$ & $(100 \%)$ \\
\hline
\end{tabular}

Table 6.5 Marital status and place of work

\begin{tabular}{lccc}
\hline Marital status & \multicolumn{2}{c}{ Place of work } & \multirow{2}{*}{ Total } \\
\cline { 2 - 3 } & Office & Telework & \\
\hline Married & 381 & 108 & 489 \\
& $(45.2 \%)$ & $(52.9 \%)$ & $(46.7 \%)$ \\
Unmarried & 442 & 88 & 530 \\
& $(52.4 \%)$ & $(43.1 \%)$ & $(50.6 \%)$ \\
Others & 3 & 1 & 4 \\
& $(0.3 \%)$ & $(0.5 \%)$ & $(0.4 \%)$ \\
Not available & 17 & 7 & 24 \\
& $(2.0 \%)$ & $(3.4 \%)$ & $(2.3 \%)$ \\
Total & 843 & 204 & 1047 \\
& $(100.0 \%)$ & $(100.0 \%)$ & $(100.0 \%)$ \\
\hline
\end{tabular}

more managerial employees (75 per cent) who were teleworking than non-managerial employees ( 25 per cent). However, the sample was also proportionately distributed, with managerial employees making up 74 per cent of the sample, and non-managerial employees only 26 per cent (Table 6.7), making it difficult for us to say with certainty that it is more common to find managers teleworking than non-managers.

Ninety-nine per cent of employees interviewed were full-time employees, so most of the employees who were teleworking ( 98 per cent) were also full- 
Table 6.6 Educational level (highest qualification) and place of work

\begin{tabular}{lccc}
\hline \multirow{2}{*}{$\begin{array}{l}\text { Educational level } \\
\text { (highest qualification) }\end{array}$} & \multicolumn{2}{c}{ Place of work } & \multirow{2}{*}{ Total } \\
\cline { 2 - 3 } & Office & Telework & \\
\hline Up to Tenth Standard & 6 & 0 & 6 \\
Up to Twelfth Standard & $(0.7 \%)$ & $(0.0 \%)$ & $(0.6 \%)$ \\
Undergraduate & 13 & 3 & 16 \\
& $(1.5 \%)$ & $(1.5 \%)$ & $(1.5 \%)$ \\
Diploma holder & 9 & 1 & 10 \\
& $(1.1 \%)$ & $(0.5 \%)$ & $(1.0 \%)$ \\
Graduate & 61 & 16 & 77 \\
& $(7.2 \%)$ & $(7.9 \%)$ & $(7.4 \%)$ \\
Postgraduate diploma & 388 & 72 & 460 \\
holder & $(46.1 \%)$ & $(35.5 \%)$ & $(44.0 \%$ \\
Postgraduate & 29 & 9 & 38 \\
& $(3.4 \%)$ & $(4.4 \%)$ & $(3.6 \%)$ \\
Not available & 335 & 102 & 437 \\
Total & $(39.8 \%)$ & $(50.3 \%)$ & $(41.8 \%)$ \\
& 1 & 0 & 1 \\
& $(0.1 \%)$ & $(0.0 \%)$ & $(0.1 \%)$ \\
\hline
\end{tabular}

Table 6.7 Position in the organization and place of work

\begin{tabular}{llcl}
\hline $\begin{array}{l}\text { Position in the } \\
\text { organization }\end{array}$ & \multicolumn{2}{c}{ Place of work } & \multirow{2}{*}{ Total } \\
\cline { 2 - 3 } & Office & Telework & \\
\hline Non managerial & 221 & 51 & 272 \\
& $(26.2 \%)$ & $(25.0 \%)$ & $(26.0 \%)$ \\
Managerial & 621 & 153 & 774 \\
& $(73.8 \%)$ & $(75.0 \%)$ & $(74.0 \%)$ \\
Total & 842 & 204 & 1046 \\
& $(100 \%)$ & $(100 \%)$ & $(100 \%)$ \\
\hline
\end{tabular}

time employees (Table 6.8). Regarding the days of work and employment, we find that days of work were more intense for full-time teleworkers rather than for part-time teleworkers. While there were 11 per cent of full-timers working every day, none of the part-timers worked every day. However, caution is required here because only four part-timers were included in the sample, compared with 200 full-timers (Table 6.9). However, we also found 
Table 6.8 Type of employment and place of work

\begin{tabular}{|c|c|c|c|}
\hline \multirow{2}{*}{$\begin{array}{l}\text { Type of } \\
\text { employment }\end{array}$} & \multicolumn{2}{|c|}{ Place of work } & \multirow[t]{2}{*}{ Total } \\
\hline & Office & Telework & \\
\hline Full-time & $\begin{array}{l}835 \\
(99.1 \%)\end{array}$ & $\begin{array}{l}200 \\
(98.0 \%)\end{array}$ & $\begin{array}{l}1035 \\
(98.9 \%)\end{array}$ \\
\hline Part-time & $\begin{array}{l}8 \\
(0.9 \%)\end{array}$ & $\begin{array}{l}4 \\
(2.0 \%)\end{array}$ & $\begin{array}{l}12 \\
(1.1 \%)\end{array}$ \\
\hline Total & $\begin{array}{c}843 \\
(100 \%)\end{array}$ & $\begin{array}{c}204 \\
(100 \%)\end{array}$ & $\begin{array}{l}1047 \\
(100 \%)\end{array}$ \\
\hline
\end{tabular}

Table 6.9 Employment status and days of work

\begin{tabular}{llcccc}
\hline $\begin{array}{l}\text { Employment } \\
\text { status }\end{array}$ & None & $\begin{array}{c}1-2 \text { days per } \\
\text { week }\end{array}$ & $\begin{array}{c}\text { 3-6 days per } \\
\text { week }\end{array}$ & Every day & Total \\
\hline Full-time & 3 & 1 & 175 & 22 & $\mathrm{~N}=200$ \\
& $1.5 \%$ & $0.5 \%$ & $87.0 \%$ & $11 \%$ & $\mathrm{~N}=4$ \\
Part-time & 0 & 0 & 4 & 0 & \\
& $0.0 \%$ & $0.0 \%$ & $100.0 \%$ & $0.0 \%$ & \\
\hline
\end{tabular}

freelancers, mainly those from the IT industry, who were teleworking but were not included in the sample.

\section{EFFECTS OF TELEWORK}

\section{Hours of Work}

Most of the respondents worked in jobs which had regular schedules ( 98.5 per cent). Eighty-four per cent of all those working from the office worked for nine hours a day or less. This dropped to 81 per cent for those teleworking (Table 6.10). This means that, although some of those working from the office worked long hours, the numbers increased slightly for those working from places other than the office. Sixty-one per cent of the respondents stated that they worked overtime. This figure was 63 per cent for those working from office and 70 per cent for teleworkers (Table 6.11). Thus, there were more teleworkers who worked overtime on a daily basis. Likewise, 54 per cent of the respondents who worked in the office reported that they worked beyond 6.00 p.m., but this figure was higher (66 per cent) 
Table 6.10 Official hours of work and place of work

\begin{tabular}{llcl}
\hline \multirow{2}{*}{$\begin{array}{l}\text { Official hours of } \\
\text { work }\end{array}$} & \multicolumn{2}{c}{ Place of work } & \multirow{2}{*}{ Total } \\
\cline { 2 - 3 } & Office & Telework & \\
\hline Less than 9 hours & 707 & 161 & 868 \\
& $(84.1 \%)$ & $(80.9 \%)$ & $(83.5 \%)$ \\
More than 9 hours & 134 & 38 & 172 \\
& $(15.9 \%)$ & $(19.1 \%)$ & $(16.5 \%)$ \\
Total & 841 & 199 & 1040 \\
& $(100.0 \%)$ & $(100.0 \%)$ & $(100.0 \%)$ \\
\hline
\end{tabular}

Table 6.11 Overtime work and place of work

\begin{tabular}{|c|c|c|c|}
\hline \multirow[t]{2}{*}{ Overtime work } & \multicolumn{2}{|c|}{ Place of work } & \multirow[t]{2}{*}{ Total } \\
\hline & Office & Telework & \\
\hline Yes & $\begin{array}{l}530 \\
(62.9 \%)\end{array}$ & $\begin{array}{l}143 \\
(70.1 \%)\end{array}$ & $\begin{array}{l}673 \\
(61.3 \%)\end{array}$ \\
\hline No & $\begin{array}{l}313 \\
(37.1 \%)\end{array}$ & $\begin{array}{l}61 \\
(29.9 \%)\end{array}$ & $\begin{array}{l}374 \\
(35.7 \%)\end{array}$ \\
\hline Total & $\begin{array}{l}843 \\
(100.0 \%)\end{array}$ & $\begin{array}{l}204 \\
(100.0 \%)\end{array}$ & $\begin{array}{l}1047 \\
(100.0 \%)\end{array}$ \\
\hline
\end{tabular}

for those who were teleworking (Table 6.12). A further disaggregation of teleworkers reveals that the figure was even higher ( 75 per cent) for those who were working from a combination of spaces, that is the office and any other place besides the office. Similarly, 71 per cent of the sample worked on weekends (Saturday or Sunday, or both). This figure was higher for teleworkers ( 79 per cent), as compared with office-based employees (69 per cent). See Table 6.13. Sixty per cent of those interviewed stated that they worked for six days or more in a week that included Sundays (Table 6.14). Those working from the office (58 per cent) were better off compared with teleworkers (67 per cent). Thus, there was an overall intensification of work, which was greater for teleworkers. This situation has to be seen in light of the new government initiative, 'Make in India', which probably will further intensify work.

Only about 32 per cent of respondents never worked for more than 48 hours a week (Table 6.15). While 46 per cent of respondents working from an office always worked for more than 48 hours a week, 48 per cent of those teleworking also did so. Thus, the percentage of teleworkers (66 per 
Table 6.12 Working after 6 p.m. and place of work

\begin{tabular}{|c|c|c|c|}
\hline \multirow[t]{2}{*}{ Work after 6 p.m. } & \multicolumn{2}{|c|}{ Place of work } & \multirow[t]{2}{*}{ Total } \\
\hline & Office & Telework & \\
\hline Yes & $\begin{array}{l}456 \\
(54.2 \%)\end{array}$ & $\begin{array}{l}135 \\
(66.2 \%)\end{array}$ & $\begin{array}{l}591 \\
(56.5 \%)\end{array}$ \\
\hline No & $\begin{array}{l}382 \\
(45.4 \%)\end{array}$ & $\begin{array}{l}69 \\
(33.8 \%)\end{array}$ & $\begin{array}{l}451 \\
(43.1 \%)\end{array}$ \\
\hline No fixed time & $\begin{array}{l}4 \\
(0.5 \%)\end{array}$ & $\begin{array}{l}0 \\
(0.0 \%)\end{array}$ & $\begin{array}{c}4 \\
(0.4 \%)\end{array}$ \\
\hline Total & $\begin{array}{l}842 \\
(100.0 \%)\end{array}$ & $\begin{array}{l}204 \\
(100.0 \%)\end{array}$ & $\begin{array}{l}1046 \\
(100.0 \%)\end{array}$ \\
\hline
\end{tabular}

Table 6.13 Work on weekends and place of work

\begin{tabular}{|c|c|c|c|}
\hline & \multicolumn{2}{|c|}{ Where do you work from? } & \multirow[t]{2}{*}{ Total } \\
\hline & Office & Telework & \\
\hline Never & $\begin{array}{l}263 \\
(31.2 \%)\end{array}$ & $\begin{array}{l}42 \\
(20.6 \%)\end{array}$ & $\begin{array}{l}305 \\
(29.1 \%)\end{array}$ \\
\hline $\begin{array}{l}\text { Saturday or } \\
\text { Sunday, or both }\end{array}$ & $\begin{array}{l}580 \\
(68.8 \%)\end{array}$ & $\begin{array}{l}162 \\
(79.4 \%)\end{array}$ & $\begin{array}{l}742 \\
(70.9 \%)\end{array}$ \\
\hline Total & $\begin{array}{l}843 \\
(100.0 \%)\end{array}$ & $\begin{array}{l}204 \\
(100.0 \%)\end{array}$ & $\begin{array}{l}1047 \\
(100.0 \%)\end{array}$ \\
\hline
\end{tabular}

Table 6.14 Number of days of the week worked and place of work

\begin{tabular}{lccc}
\hline \multirow{2}{*}{$\begin{array}{l}\text { Number of days } \\
\text { of the week worked }\end{array}$} & \multicolumn{2}{c}{ Place of work } & \multirow{2}{*}{ Total } \\
\cline { 1 - 3 } Less than 5 & 4 & 0 & \\
& $(0.5 \%)$ & $(0.0 \%)$ & $(0.4 \%)$ \\
5 & 331 & 61 & 392 \\
& $(39.3 \%)$ & $(29.9 \%)$ & $(37.4 \%)$ \\
5.5 & 20 & 6 & 26 \\
& $(2.4 \%)$ & $(2.9 \%)$ & $(2.5 \%)$ \\
6 or more & 488 & 137 & 625 \\
& $(57.9 \%)$ & $(67.2 \%)$ & $(59.7 \%)$ \\
Total & 843 & 204 & 1047 \\
& $(100.0 \%)$ & $(100.0 \%)$ & $(100.0 \%)$ \\
\hline
\end{tabular}


Table 6.15 Work for more than 48 hours a week and place of work

\begin{tabular}{lccc}
\hline \multirow{2}{*}{$\begin{array}{l}\text { Work for more than } \\
48 \text { hours a week }\end{array}$} & \multicolumn{2}{c}{ Place of work } & \multirow{2}{*}{ Total } \\
\cline { 2 - 3 } & Office & Telework & \\
\hline Never & 281 & 56 & 337 \\
& $(33.3 \%)$ & $(27.5 \%)$ & $(32.2 \%)$ \\
Rarely (once) & 45 & 6 & 51 \\
& $(5.3 \%)$ & $(2.9 \%)$ & $(4.9 \%)$ \\
Sometimes (once or & 64 & 19 & 83 \\
twice; twice) & $(7.6 \%)$ & $(9.3 \%)$ & $(7.9 \%)$ \\
Often (Three times) & 47 & 18 & 65 \\
& $(5.6 \%)$ & $(8.8 \%)$ & $(6.2 \%)$ \\
Always (four or five & 386 & 97 & 483 \\
times) & $(45.8 \%)$ & $(47.5 \%)$ & $(46.1 \%)$ \\
Others (specify) & 20 & 8 & 28 \\
& $(2.4 \%)$ & $(3.9 \%)$ & $(2.7 \%)$ \\
Total & 843 & 204 & 1047 \\
& $(100.0 \%)$ & $(100.0 \%)$ & $(100.0 \%)$ \\
\hline
\end{tabular}

cent) who worked for more than 48 hours a week from sometimes to always was slightly higher than the figure for office-based workers (59 per cent).

Although it was obvious that those working beyond the office would take more frequent breaks, as that defined the flexibility that telework offered, we found that even those working in the office ( 45 per cent) took more than the stipulated breaks (Table 6.16), often resulting in stretched hours of work. This situation may partially account for them working more than nine hours, beyond 6.00 p.m. or on weekends, reflecting the Indian work ethic (see D'Cruz and Noronha 2012).

While 84 per cent of those working in the office stated that they did not received overtime payments for work beyond nine hours per day, this figure was 89 per cent in the case of teleworkers (Table 6.17). Only about 10 per cent of the entire sample received overtime payments for work beyond official working hours, of which 10 per cent were those working in the office and about 8 per cent were teleworkers (Table 6.18). Overall, only 3.2 per cent of employees received overtime payments that were twice their normal wages, as specified by law. This situation means that payment of overtime rates generally ceased to exist, but those working in the office still had a slightly better chance of getting such payments, which was almost non-existent for those working from places away from the office. 
Table 6.16 More than stipulated breaks and place of work

\begin{tabular}{lccc}
\hline \multirow{2}{*}{$\begin{array}{l}\text { Breaks other than } \\
\text { those stipulated }\end{array}$} & \multicolumn{2}{c}{ Place of work } & \multirow{2}{*}{ Total } \\
\cline { 2 - 3 } & Office & Telework & \\
\hline Yes & 380 & 135 & 515 \\
& $(45.1 \%)$ & $(66.2 \%)$ & $(49.2 \%)$ \\
No & 455 & 67 & 522 \\
& $(54.0 \%)$ & $(32.8 \%)$ & $(49.9 \%)$ \\
Not applicable & 6 & 2 & 8 \\
& $(0.7 \%)$ & $(1.0 \%)$ & $(0.8 \%)$ \\
Depends on & 2 & 0 & 2 \\
$\quad$ workload & $(0.2 \%)$ & $(0.0 \%)$ & $(0.2 \%)$ \\
Total & 843 & 204 & 1047 \\
& $(100.0 \%)$ & $(100.0 \%)$ & $(100.0 \%)$ \\
\hline
\end{tabular}

Table 6.17 Overtime payment and place of work

\begin{tabular}{lccc}
\hline \multirow{2}{*}{ Overtime payment } & \multicolumn{2}{c}{ Place of work } & \multirow{2}{*}{ Total } \\
\cline { 2 - 3 } & \multicolumn{2}{c}{ Office } & Telework \\
\hline Yes & 86 & 16 & 102 \\
& $(16.2 \%)$ & $(11.2 \%)$ & $(15.2 \%)$ \\
No & 444 & 127 & 573 \\
& $(83.8 \%)$ & $(88.8 \%)$ & $(84.8 \%)$ \\
Total & 530 & 204 & 1047 \\
& $(100.0 \%)$ & $(100.0 \%)$ & $(100.0 \%)$ \\
\hline
\end{tabular}

\section{Organizational and Individual Performance}

While employees' self-rating of employers' gains from the productivity of teleworking could be biased, about 80 per cent of the respondents resoundingly agreed that employers gained from teleworking in terms of increased productivity and efficiency, while 76 per cent stated that employers gained in terms of better quality of work (Table 6.19). The other parameters on which more than half of the respondents agreed or strongly agreed were cost savings (53.4 per cent), flexibility (58.3 per cent), customer satisfaction ( 60.8 per cent) and virtual teamwork (53.9 per cent). Thus, overall it seems that employers benefitted from teleworking. At the individual level, too, respondents teleworked because they believed they could achieve higher output ( 68 per cent) and better quality (68 per cent), but this percentage was not as overwhelming as in the case of employers' 
Table 6.18 Overtime rate and place of work

\begin{tabular}{lccc}
\hline Overtime rate & \multicolumn{2}{c}{ Place of work } & \multirow{2}{*}{ Total } \\
\cline { 2 - 3 } & Office & Telework & \\
\hline Less than normal & 17 & 1 & 18 \\
rate & $(2.0 \%)$ & $(0.5 \%)$ & $(1.7 \%)$ \\
Normal rate & 36 & 5 & 41 \\
& $(4.3 \%)$ & $(2.5 \%)$ & $(3.9 \%)$ \\
Twice normal rate & 26 & 7 & 33 \\
& $(3.1 \%)$ & $(3.4 \%)$ & $(3.2 \%)$ \\
Yes but amount not & 7 & 3 & 10 \\
known & $(0.8 \%)$ & $(1.5 \%)$ & $(1.0 \%)$ \\
None & 757 & 188 & 945 \\
& $(89.8 \%)$ & $(92.2 \%)$ & $(90.3 \%)$ \\
Total & 843 & 204 & 1047 \\
& $(100.0 \%)$ & $(100.0 \%)$ & $(100.0 \%)$ \\
\hline
\end{tabular}

gain (Table 6.20). The other important factors where more than half the respondents agreed or strongly agreed were saving on travel time (52.5 per cent), higher autonomy (55.9 per cent), flexibility (60.3 per cent), and control over their work schedule (50.5 per cent). Thus, the respondents stated that it was in the interest of the employer and also in their own interest that they teleworked, as they were able to achieve higher output with better quality.

More than half of those who were teleworking stated that they did not face any disturbances (55 per cent), lack of concentration (62 per cent), extra hours of work ( 53 per cent), higher performance indices ( 57 per cent) or work-life balance issues (55 per cent). At the same time, we cannot ignore that at least 20 per cent of teleworkers faced one of the difficulties listed in Table 6.21, with a total of about 32 per cent facing disturbances while working at a place away from the office.

\section{Work-Life Balance}

A substantial number of teleworking employees (51 per cent) reported that they worked all the time (Table 6.22). A substantial number (46 per cent) of them stated that they were on work-related calls quite often or most of the time, with 27 per cent on calls occasionally. Regarding getting time off to take care of personal matters, teleworking employees seemed divided: 50 per cent stated that they quite often or mostly got time off to deal with such matters, while the other half stated it was only occasionally, rarely, or 


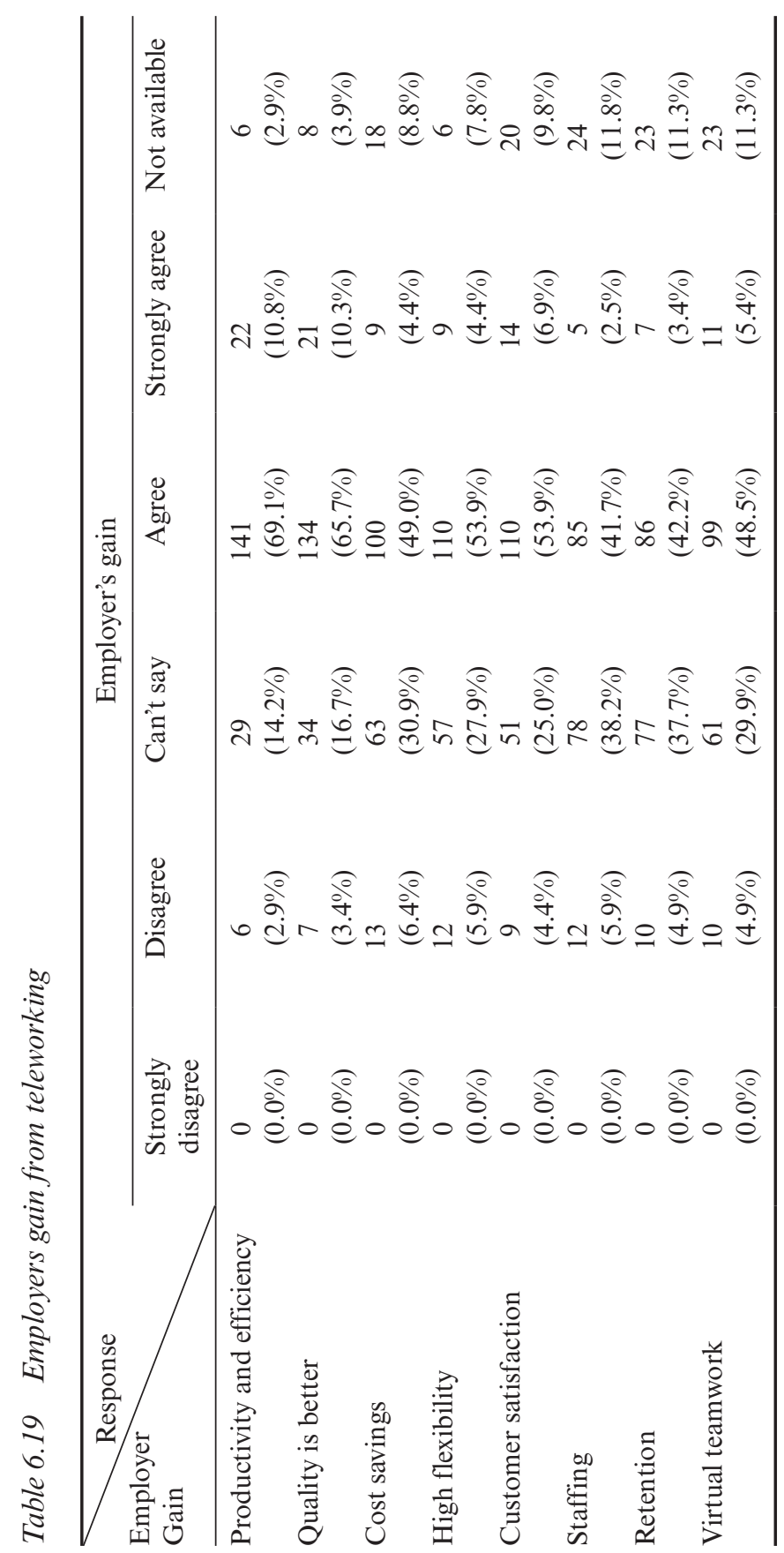




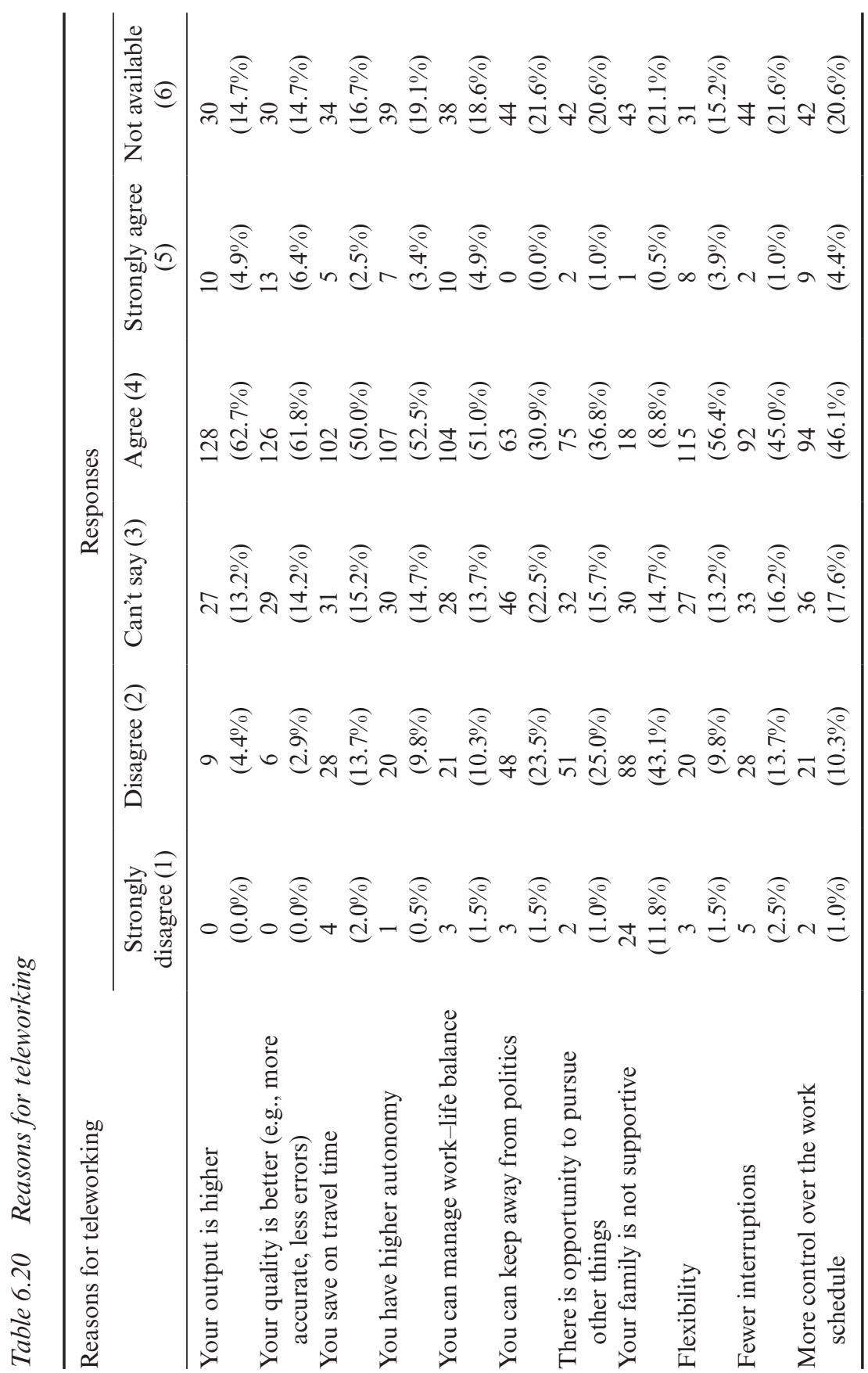


Table 6.21 Problems of teleworking

\begin{tabular}{lclllll}
\hline $\begin{array}{l}\text { Problems of } \\
\text { teleworking }\end{array}$ & \multicolumn{6}{c}{ Responses } \\
\cline { 2 - 7 } & $\begin{array}{c}\text { Strongly } \\
\text { disagree } \\
(1)\end{array}$ & $\begin{array}{c}\text { Disagree } \\
(2)\end{array}$ & $\begin{array}{c}\text { Can’t say } \\
(3)\end{array}$ & $\begin{array}{c}\text { Agree } \\
(4)\end{array}$ & $\begin{array}{c}\text { Strongly } \\
\text { agree } \\
(5)\end{array}$ & $\begin{array}{c}\text { Not } \\
\text { available } \\
(6)\end{array}$ \\
\hline Disturbance & 6 & 107 & 20 & 59 & 6 & 6 \\
& $(2.9 \%)$ & $(52.5 \%)$ & $(9.8 \%)$ & $(28.9 \%)$ & $(2.9 \%)$ & $(2.9 \%)$ \\
Lack of & 5 & 121 & 20 & 50 & 3 & 5 \\
concentration & $(2.5 \%)$ & $(59.3 \%)$ & $(9.8 \%)$ & $(24.5 \%)$ & $(1.5 \%)$ & $(2.5 \%)$ \\
Extra hours of & 3 & 105 & 21 & 48 & 14 & 13 \\
work & $(1.5 \%)$ & $(51.5 \%)$ & $(10.3 \%)$ & $(23.5 \%)$ & $(6.9 \%)$ & $(6.4 \%)$ \\
Higher perfor- & 4 & 113 & 30 & 33 & 8 & 16 \\
mance indices & $(2.0 \%)$ & $(55.4 \%)$ & $(14.7 \%)$ & $(16.2 \%)$ & $(3.9 \%)$ & $(7.8 \%)$ \\
(output, & & & & & & \\
quality, etc.) & & & & & & 17 \\
Higher controls & 3 & 106 & 29 & 43 & 6 & $(8.3 \%)$ \\
Work-life & $(1.5 \%)$ & $(52.0 \%)$ & $(14.2 \%)$ & $(21.1 \%)$ & $(2.9 \%)$ & 11 \\
balance & $(2.0 \%)$ & $(53.4 \%)$ & $(15.2 \%)$ & $(20.6 \%)$ & $(3.4 \%)$ & $(5.4 \%)$ \\
\hline
\end{tabular}

never. Nonetheless, 61 per cent argued that ICT devices helped in controlling work schedules most of the time or quite often, enabling about 35 per cent of those answering the question to take holidays quite often or most of the time. However, 47 per cent occasionally, rarely or never felt that ICT devices allowed them to take holidays when they wanted to do so. When it came to sleep, 67 per cent felt that it was not disrupted, with only 21 per cent stating it did get disrupted. Devices disrupted spending time with friends in 75 per cent of the cases occasionally, rarely or never. Finally, 60 per cent of the teleworkers were never, rarely or occasionally expected to work on holidays.

Most of those teleworking maintained strict working hours (53 per cent) and separate work spaces to enable them to work effectively (Table 6.23). The former called for self-responsibility and control.

We now turn to the broad policies that the five organizations that we studied formulated regarding telework. 


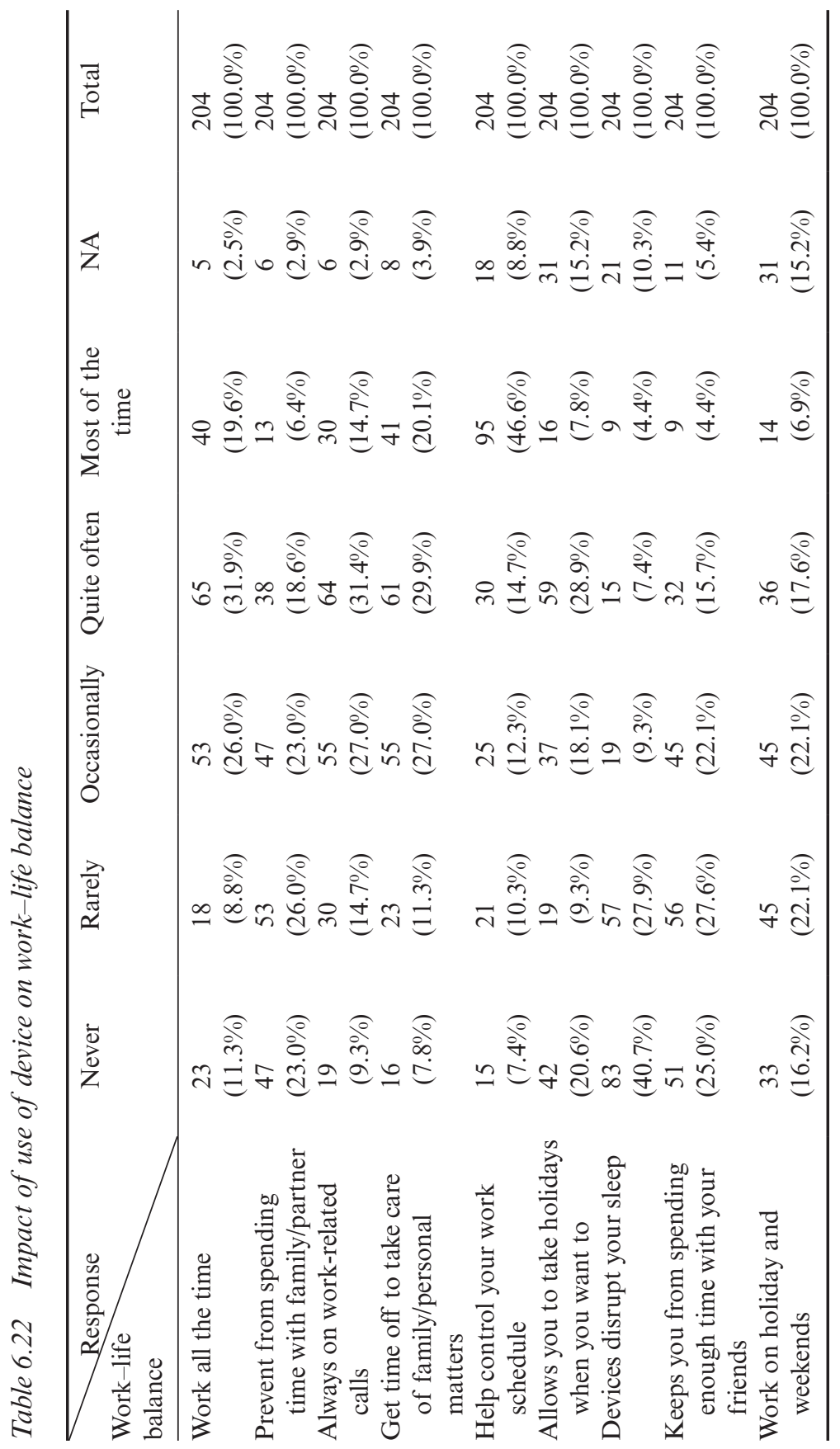


Table 6.23 Strategies for reconciling issues of work-life balance

Strict working hours

109

$(53.4 \%)$

Separate space for work

99

$(48.5 \%)$

Family member and friend are told not to disturb

19

$(19 \%)$

Family members and friends visit only by prior opportunity

48

$(24 \%)$

Visitors and attended by family members

71

$(35 \%)$

\section{POLICY RESPONSES TO TELEWORK}

The first organizations to introduce teleworking to India were multinationals such as IBM and American Express, which were soon followed by Indian organizations, particularly in the IT sector (Raghuram 2014). Raghuram (2014) argues that the lead taken by the IT sector was because of its characteristics, such as geographically distributed customers and team members. This implies that teleworking cannot be a universal policy covering all jobs and industries. In those jobs and industries that require the physical presence of employees and where issues related to privacy, control and data security are critical, teleworking cannot be introduced. In addition, although organizations involved in telework ensure a relatively more empowering work relationship (Gothoskar 2000), managers may resist teleworking - especially in high power distance countries such as India - because of their inability to control or monitor physically dispersed subordinates, who by teleworking also reduce their dependence on the organizations. To reclaim their power, the supervisors may increase direction and work control procedures, or even increase the surveillance of subordinates electronically. Consequently, managers called teleworkers frequently to check on them and pressurize them to come to the office more frequently.

The above mindset probably is reflected in organizational polices that require teleworkers to be available at any hour, log on for a given number of hours, complete a given amount of work every day, contact the office at given intervals and have regular email communications that are followed up by weekly meetings. Further, in order to ensure that teleworking works well, organizations should have a good management by objectives programme and a precise job description which ensures that deliverables are 
achieved and goals are met. Moreover, teleworking is not an entitlement, and requires prior management approval which is based on a review of the eligibility criteria and the objective of balancing employee and business needs. Organizations typically allowed only those who had worked as fulltime office employees, had achieved a certain level of proficiency and had familiarized themselves with the firm's polices and the manager concerned to opt for telework.

In summary, the major concern of organizations implementing telework in India is control (Mitter 2000). For instance, in some cases organizations took care of issues of connectivity; however, issues such as power failures, or telephone or computer breakdowns were not entertained, since the organization had no way of verifying them. On these types of occasions, teleworkers were either expected to apply for leave or work in the office. Nonetheless, teleworking was problematic for conventional strategies of managerial control, which emphasize the visibility and presence of workers. A range of mechanisms, such as surveillance devices, target setting and home visits, are devised by managers to compensate for the loss of visibility and presence of home-located employees. Thus, organizations intensify bureaucratic controls in order to compensate for the perceived reduction of direct supervision of teleworkers (Noronha and D'Cruz 2008a). Not surprisingly, teleworkers felt that office-goers could get away with underperforming. Most of the office employees did much less work and had many distractions, such as food breaks, game breaks or just whiling away their time (Noronha and D'Cruz 2008b). This situation is likely to make teleworkers cautious and overly concerned about their evaluations and visibility, with some in the long run giving up teleworking if the supervisor's control is counterproductive (Raghuram 2014).

Normative control is also invoked to ensure the creation and maintenance of a strong culture that increases employees' commitment to organizational values and their identification with the organization (Noronha and D'Cruz 2008b). Teleworkers were expected to also be self-accountable, have a high sense of moral and professional integrity, and be self-motivated, self-governed and self-managed (Rajan 2000). Continued socialization of employees was achieved through the occasional gathering of teleworkers in the office to allow them to participate in the necessary rituals. The office intranet and email system were instrumental in maintaining teleworkers' connectedness with their employing organization. Through these media, employees were kept abreast of issues related to work, leisure, administration and policies, among others, and were invited to participate in various activities (Noronha and D'Cruz 2008b).

Another issue pertains to infrastructure. Teleworkers are expected to install an inverter in their houses to manage power failures and utilize their 
Table 6.24 Preferred place of work as a teleworker

\begin{tabular}{lc}
\hline Preferred place of work & Frequency $(\%)(\mathrm{n}=204)$ \\
\hline Home & 97 \\
Short working space & $(47.6 \%)$ \\
& 21 \\
Internet café & $(10.3 \%)$ \\
Public space & 21 \\
& $(10.3 \%)$ \\
Travel & 20 \\
& $(9.8 \%)$ \\
\hline
\end{tabular}

own equipment, although software and a fixed amount of telephone costs are provided by the organization. The anticipated benefits forced teleworkers to make investments in work space, electricity, computer hardware, Internet connectivity and unlimited power supply (UPS) in their homes. This amount increased if employer organizations wanted the employees to purchase branded computers instead of cheaper assembled ones. A few teleworkers converted their one-room house into a virtual office, while others were planning to buy a two-bedroom apartment so that teleworking would become more comfortable (Noronha and D'Cruz 2008b). Forty-eight per cent of those teleworking in our survey worked from home (Table 6.24).

To enable employees to work from home, employers mainly provided laptops (58 per cent) and desktop computers ( 31 per cent). The other types of devices provided were telephones, that is, land lines and mobile phones and smartphones. See Table 6.25. Besides providing computing facilities and telephones, 56 per cent of employees stated that employers paid for the maintenance of laptops and another 54 per cent stated that employers paid for the maintenance of smartphones (Table 6.26).

Regarding careers, the response is mixed, with some arguing that telework did not hamper career prospects, while others argue that out of sight was out of mind and that the productivity of teleworkers declines over a period of time (Chowdary and Jayakumar 2009). Teleworkers stated that if they wanted to move up the organizational hierarchy, they had to return to office-based work (Noronha and D'Cruz 2008b). Thus, those who are teleworking are advised to over-communicate by writing articles in company newsletters and other forums, so that they can compensate for their lack of physical presence and become more visible to the organization (Chowdary and Jayakumar 2009).

The decision to telework was motivated primarily by domestic or 
Table 6.25 Does your employer provide devices?

\begin{tabular}{lc}
\hline Devices & Frequency $(\%) \mathrm{n}=204$ \\
\hline Smartphones & 50 \\
& $(24.5 \%)$ \\
Tablets & 20 \\
& $(9.8 \%)$ \\
Laptops & 118 \\
& $(57.8 \%)$ \\
Desktops & 64 \\
& $(31.4 \%)$ \\
Landline telephones & 56 \\
& $(27.5 \%)$ \\
Mobile phone & 36 \\
& $(22.8 \%)$ \\
Video-audio tools (webcams, video & 23 \\
cameras, etc.) & $(11.3 \%)$ \\
\hline
\end{tabular}

Table 6.26 Employer pays for maintenance cost of devices

\begin{tabular}{lc}
\hline Devices & Frequency $(\%)(\mathrm{n}=204)$ \\
\hline Smartphones & 109 \\
& $(53.5 \%)$ \\
Tablets & 24 \\
& $(11.7 \%)$ \\
Laptop & 115 \\
& $(56.4 \%)$ \\
Desktop & 57 \\
& $(28 \%)$ \\
Landline telephones & 50 \\
& $(24.5 \%)$ \\
Mobile phones & 72 \\
& $(35.3 \%)$ \\
Video-audio tools & 31 \\
\end{tabular}

family concerns, and teleworking was construed as an opportunity to continue in the realm of paid employment, while simultaneously fulfilling home-related responsibilities (Noronha and D'Cruz 2008b). However, teleworking was not recommended as a substitute for childcare, and some organizations even specify that the location of the teleworking should be 
free of distractions for a major part of the day. Most of the successful teleworking programmes require that no child under 5 years of age is living at home (Raghuram 2014).

Nonetheless, for teleworkers to get their voice heard, traditional trade unionism may be inadequate to demand the rights of dispersed teleworkers, but teleworkers do require the support of collective and cooperative actions. For instance, women who opt for teleworking in the absence of adequate childcare provisions may require such assistance (Mitter 2000). Further, Noronha and D'Cruz (2008b) note that some teleworkers formed an exclusive e-group through which they maintained contact with each other and shared their concerns. They met management as a group once every three months at the office. The e-group and group meetings helped the teleworkers to collectively redress their problems related to connectivity, holiday compensation, attendance and other inequities between them and office-based workers.

\section{CONCLUSION}

Early work on teleworking in India often focused on its feasibility in terms of availability of telecommunications infrastructure. Power failures and fluctuations meant installation of generators to ensure a steady flow of electricity and thus connectivity (Noronha and D'Cruz 2008b). Since then, broadband penetration has increased many times over, with mobile phone connections becoming common, thus increasing the feasibility of a telework programme. More recently, the Digital India programme launched by the Government of India to provide high-speed Internet connectivity across the length and breadth of the country (GOI 2015) will boost the possibilities of telework. Evidence in support of this comes from our survey, where we find that, in comparison to earlier studies, which circumscribed telework to IT, finance and media, the phenomenon of telework has spread to other sectors as well, such as hospitality, telecommunications and manufacturing.

We begin with some misconceptions related to telework in India. It is often contended that those who are teleworking are married. For instance, Lila and Anjaneyulu (2013) argue that the marital status of employees influenced the choice of telework, with married people teleworking more frequently compared with unmarried people. In our sample, too, 53 per cent of those teleworking were married, but at the same time 47 per cent were unmarried. Thus, those availing themselves of the facility to telework need not be married. Another interesting finding of the study is that it is often stated that telework in India is a gendered phenomenon, that is, the 
decision to telework is perceived as being motivated primarily by domestic/ family concerns and is construed as an opportunity for women to continue in the realm of paid employment, while simultaneously fulfilling homerelated responsibilities (Aundhkar et al. 2000; Gothoskar 2000; Irani et al. 2000; Noronha and D'Cruz 2008b). However, when disaggregating by gender, we found that more women worked in the office ( 82 per cent) than teleworked (18 percent), while the ratio for men was similar, that is, 80 per cent working from the office and 20 per cent teleworking. Thus, contrary to the prevailing belief, women do not always prefer to telework and men are also interested in teleworking. This may be related to the policy of organizations, which does not distinguish between men and women when deciding who teleworks.

Teleworking was not a universal policy covering all jobs and industries. In those jobs and industries that require the physical presence of employees and where issues related to privacy, control and data security are critical, teleworking cannot be introduced (Chowdary and Jayakumar 2009; Mitter, 2000; Rajan 2000). Therefore, in most cases the final decision lies with the manager. In addition, the major concern of organizations implementing telework is control, which emphasizes the visibility and presence of workers. Organizations only allow those who had worked as full-time office employees and had achieved a certain level of proficiency to opt for telework. Telework was not recommended as a substitute for childcare, and some organizations even specify that the location of the teleworking should be free of distractions for a major part of the day. Further, issues such as power failure or telephone or computer breakdown were not entertained, since the organization had no way of verifying them. On these occasions, teleworkers were either expected to apply for leave or work in the office (Noronha and D'Cruz 2008b). Also, although organizations involved in telework ensure a relatively more empowering work relationship (Gothoskar 2000), managers called teleworkers frequently to check on them and pressurize them to come to the office more frequently (Raghuram 2014). This mindset probably is reflected in organization polices that require teleworkers to be available at any hour, $\log$ on for a given number of hours, complete a given amount of work every day, touch base with the office at given intervals (Rajan 2000), and have regular email communications which are followed up by weekly meetings (Aundhkar et al. 2000). In addition, normative control is also invoked to ensure the creation and maintenance of a strong culture that increases employees' commitment to organizational values and their identification with the organization (Noronha and D'Cruz 2008b). Teleworkers are expected to be self-accountable, have a high sense of moral and professional 
integrity, and be self-motivated, self-governed and self-managed (D'Cruz and Noronha 2006; Rajan 2000).

Consequently, more teleworkers worked long hours and at weekends, including Sundays, compared with those working from office, reflecting the Indian work ethic (see D'Cruz and Noronha 2012; Noronha et al. 2018). Thus, although there was an overall intensification of work, it was higher for teleworkers. Similarly, it was also clear that working in the office did make a difference for performance appraisals, promotions, privileges, leave and holidays, and overtime payments. Not surprisingly, teleworkers felt that office-goers could get away with underperformance. Therefore, those teleworking are advised to over-communicate by writing articles in company newsletters and other forums, so that they could compensate for their lack of physical presence and become more visible to the organization (Chowdary and Jayakumar 2009). Moreover, traditional trade unions are inadequate to address these issues, but teleworkers do resort to collective and cooperative actions. For instance, teleworkers formed an exclusive e-group through which they maintained contact with each other and shared their concerns with management (Noronha and D'Cruz, 2008b). Further, individually most of those teleworking maintained strict working hours $(53 \%)$ and separate work spaces to deal with issues of work-life balance.

Finally, we recommend the following for organizations wanting to introduce teleworking arrangements:

1. Organizations should create a culture that is supportive of teleworking. This means that teleworkers should be given the assurance that they will not be discriminated against, especially in terms of pay, benefits and privileges, training, deliverables and career progression.

2. Organizations should take responsibility for communicating and holding regular meetings with employees instead of than putting the burden of this on employees.

3. Technical support should be provided to teleworking employees in case of computer breakdown or non-performing software applications.

4. Proper forums such as e-groups and WhatsApp groups should be created for teleworkers to share their concerns between themselves and the management.

5. Supervisors should clearly instruct subordinates about their roles and responsibilities when allowing or opting to telework, so as to avoid possible misunderstandings and allow the organization to reap the benefits of telework.

6. Get-togethers should be organized for the teleworkers and their officebased colleagues, so that they get to know each other and operations can take place seamlessly. 
7. There should be an effort to build trust between supervisors and subordinates because this is a core requirement for effective teleworking. This would reduce supervisors' need to micro-manage teleworkers.

8. Supervisors' concerns should be restricted to getting the job done at the required time.

9. It is impractical to restrict teleworking only to jobs whose deliverables can be well defined; instead, even jobs that lend themselves to being performed autonomously beyond the office should be offered for teleworking.

10. Of course, clarity and agreement on deliverables can help to foster effective telework arrangements.

11. The option of working in the office should be available to those teleworking, so that productivity can be enhanced and issues of isolation while teleworking can be handled effectively. To enable this, the organization should provide the required infrastructure.

12. Organizations should provide the necessary equipment for working away from the office and reimburse employees for any related expenses involved in teleworking.

13. The legal framework and grievance-handling procedures available to office workers should also be made available to teleworkers.

14. Organizations should share their best practices with each other, so that the benefits of teleworking can be reaped by everyone.

\section{REFERENCES}

Aundhkar, A., Vaz, N., Pillai, G.A., Murthy, D.L.N., Thakar, S.S. and Gothoskar, S. (2000), 'Nature of teleworking in key sectors: case studies of financial, media and software sectors in Mumbai', Economic and Political Weekly, 35 (26), 2277-92.

Chowdary, N. and Jayakumar, V. (2009), 'Telecommuting: a perk or prerequisite?', Structured Assignment Ref. No. 410-012-4, IBS Case Development Centre, Hyderabad.

D'Cruz, P. and Noronha, E. (2006), 'Being professional: organizational control in Indian call centers', Social Science Computer Review, 24 (3), 342-61.

D'Cruz, P. and Noronha, E. (2012), 'High commitment management practices reexamined: the case of Indian call centres', Economic and Industrial Democracy, 33 (2), 185-205.

Gothoskar, S. (2000), 'Teleworking and gender', Economic and Political Weekly, 35 (26), 2293-8.

Government of India (GOI) (2015), Digital India, New Delhi: Department of Electronics \& Information Technology (DeitY) Ministry of Communications and Information Technology.

Irani, A., Gothoskar, S. and Sharma, J.C. (2000), 'Potential and prevalence of teleworking in Mumbai', Economic and Political Weekly, 35 (26), 2269-76. 
Jones, C. (2005), 'Teleworking: the quiet revolution, 2005 update', 14 September, ID No. G00122284, Gartner Research, Stamford, CT.

Lila, P. and Anjaneyulu, M. (2013), 'Modeling the choice of tele-work and its effects on travel behaviour in Indian context', Procedia - Social and Behavioral Sciences, 104 (2 December), 553-62.

Mitter, S. (2000), 'Teleworking and teletrade in India: combining diverse perspectives and visions', Economic and Political Weekly, 35 (26), 2241-52.

Mitter, S. and Sen, A. (2000), 'Can Calcutta become another Bangalore? Looking for windows of opportunity in international telework', Economic and Political Weekly, 35 (26), 2263-8.

Noronha, E. and D'Cruz, P. (2008a), 'Seeking the future: after-hours telecommuters in India's medical transcription industry', Labour and Management in Development, 8 (1), 15-26.

Noronha, E. and D'Cruz, P. (2008b), 'The dynamics of teleworking case studies of women medical transcriptionists from Bangalore, India', Gender, Technology and Development, 12 (2), 157-83.

Noronha, E., D’Cruz, P. and Banday, M.U.L. (2018), 'Navigating embeddedness: experiences of Indian IT suppliers and employees in the Netherlands', Journal of Business Ethics, 21 November, doi.org/10.1007/s10551-018-4071-3.

Raghuram, S. (2014), 'Telecommuting in India: pitfalls and possibilities', South Asian Journal of Human Resources Management, 1 (2), 207-20.

Rajan, P. (2000), 'Teleworking: training and educational needs', Economic and Political Weekly, 35 (26), 2299-304. 